J. Clin. Chem. Clin. Biochem.

Vol. 23, 1985, pp. $711-717$

\title{
Changes of Alkaline Phosphatase, Inorganic Phosphorus and Total Calcium in Sera of 11 to 17 Year Old Healthy Adolescents, and their Relationship to Growth
}

\author{
By K. Widhalm and M. Hölzl \\ Universitäts-Kinderklinik Wien, Wien, Österreich
}

(Received December 7, 1984/May 6, 1985)

Herrn Professor Dr. Erich Kaiser zum 60. Geburtstag gewidmet

Summary: A semi-longitudinal study in 111 healthy school children, 11 years old, was started in May 1976 to evaluate age-related "normal-ranges" of two so-called "routine" blood parameters during adolescence. Follow-up examinations were performed at one-year intervals until 1982. In this paper growth velocity is described and results of estimations of alkaline phosphatase, inorganic phosphorus $\left(\mathrm{P}_{\mathrm{i}}\right)$ and total calcium (Ca) are presented and compared with values in the literature.

Peak growth velocity in girls $(5.94 \pm 1.92 \mathrm{~cm} /$ year) occurred between 11 and 12 years, in boys $(7.73 \pm 2.4$ $\mathrm{cm} /$ year) between the age of 12 and 13 years; from the age of 14 years onwards boys were significantly taller than girls. A strong relationship $(p<0.05)$ between growth and alkaline phosphatase could be shown throughout the period observed. Alkaline phosphatase activity varied within a wide range and reached mean peak values at the age of 11 years in girls $(470.9 \pm 114.8 \mathrm{U} / \mathrm{l})$ and the age of 13 in boys $(514.4 \pm 135.7$ $\mathrm{U} / \mathrm{l})$.

Afterwards, alkaline phosphatase activity decreased towards adult levels. Inorganic phosphorus constantly decreased in both boys and girls until the age of 16, while from the age of 16 to 17 years a significant increase could be observed in both sexes. Total calcium values showed a significant increase between 12 and 13 years in boys and between 13 and 14 years in girls; after the age of 14 values decreased significantly in both sexes.

Our data strongly support the assumption that the known changes of alkaline phosphatase and $\mathrm{P}_{\mathrm{i}}$ are mainly due to growth and probably secondarily due to sex hormone changes.

Änderungen der alkalischen Phosphatase, des anorganischen Phosphors und des Calciums im Serum gesunder 11- bis 17jähriger Jugendlicher und deren Bezug zum Wachstum

Zusammenfassung: Im Maị 1976 wurde an 111 gesunden 11jährigen-Schulkindern eine semi-longitudinale Studie begonnen mit dem Ziel, die Altersabhängigkeit verschiedener sogenannter „Routine“-Blutkenngrößen während der Adoleszenz er erfassen. Weitere Untersuchungen wurden in jährlichen Abständen bis 1982 durchgeführt. In dieser Arbeit werden die Wachstumsgeschwindigkeit beschrieben und die Ergebnisse der Bestimmungen von alkalischer Phosphatase, anorganischem Phosphor $\left(\mathrm{P}_{\mathrm{i}}\right)$ und Gesamt-Calcium $(\mathrm{Ca})$ dargelegt und mit der Literatur verglichen.

Die größte Wachstumsgeschwindigkeit $(5,94 \pm 1,92 \mathrm{~cm} / \mathrm{Jahr})$ bei den Mädchen wurde zwischen dem 11. und 12. Lebensjahr, bei den Knaben $(7,73 \pm 2,4 \mathrm{~cm} / \mathrm{Jahr})$ zwischen dem 12. und 13. Lebensjahr beobachtet. Vom 14. Lebensjahr an waren die Knaben signifikant größer als die Mädchen. Während der gesamten Beobachtungszeit bestand zwischen dem Wachstum und der Aktivität der alkalischen Phosphatase eine enge Beziehung ( $<<0,05)$. Die katalytische Konzentration der alkalischen Phosphatase zeigte eine große Streubreite und erreichte ihren mittleren Spitzenwert bei den Mädchen mit 11 Jahren $(470,9 \pm 114,8 \mathrm{U} / \mathrm{l})$, bei 
den Knaben mit 13 Jahren $(514,4 \pm 135,7$ U/1). Danach sank die alkalische Phosphatase zu Erwachsenenwerten ab. Der anorganische Phosphor sank bei beiden Geschlechtern konstant bis zum Alter von 16 Jahren $a b$, zwischen dem 16. und 17. Lebensjahr konnte bei Mädchen wie bei Knaben ein signifikanter Anstieg beobachtet werden. Das Gesamt-Calcium stieg zwischen dem 12. und 13. Lebensjahr bei den Knaben und zwischen dem 13. und 14. Lebensjahr bei Mädchen an; nach dem 14. Lebensjahr sanken die Werte bei beiden Geschlechtern. Die Ergebnisse der vorliegenden Studie unterstützen die Annahme, daß die bekannten Veränderungen bei der alkalischen Phosphatase und beim $P_{i}$ hauptsächlich durch daș Wachstum und erst in zweiter Linie durch Änderungen der Sexualhormone zustandekommen.

\section{Introduction}

In recent decades laboratory tests of blood, urine and other biological fluids have become increasingly important for the diagnosis of many diseases of the early detection of subclinical, biochemically defined metabolic disturbances. For this purpose it seems to be of great importance that welldefined reference values are available, and that physiological changes of so-called "normal values" are taken into consideration, particularly in those parameters that are known to vary with age and sex. For most parameters clear-cut borderlines for an adult population have been established, but these "normal ranges" cannot be transferred for the use in the pediatric age group. This is true in particular for parameters which are influenced more or less directly by growth or sex hormones. One of these parameters is alkaline phosphatase catalytic activity $(1-4,11-17)$. In addition age-related changes for total calcium and inorganic phosphorus have been described earlier (4, $19,21-25)$. Due to the accelerated growth in the last decade, these known physiological changes have to be defined for the entire population of adolescents (18). Furthermore it is necessary to investigate other blood constituents for any age- or sex-related changes that have not so far been recognized as important. Although many cross-sectional studies regarding "normal values" in children and adolescents have been carried out in the past, only a few data from longitudinal studies are available $(2,16,23)$. Furthermore it should be considered that laboratory methods used in previous reports differ greatly, so the results cannot be compared without reservation.

In order to find out whether the reported "normal ranges" correspond with those in our youngest population and whether a strong correlation can be found between growth and biochemical parameters, a 7year longitudinal study in 111 healthy adolescents was performed. The programme included the estimation of all routine blood parameters, vitamins, lipoproteins and anthropometric data. Thus, we were able to follow up the changes of these parameters through the whole period of adolescence in the same group of children. In this paper, results for alkaline phosphatase, inorganic phosphorus $\left(\mathrm{P}_{\mathrm{i}}\right)$ and total calcium (Ca) in their relation to physical growth are presented. As some of the children did not participate at all follow-up examinations the presented data are only "semi-longitudinal", because all children were included in our calculations. However, a statistical analysis showed that there are no significant differences between these and the strictly longitudinal data (5).

\section{Subjects and Methods}

Healthy Austrian school children $(n=111)$ from 2 schools near Vienna, 54 boys and 57 girls, with a mean age of $11.3 \pm$ 0.6 years, were first seen in May 1976. At the follow-up visits, performed each May/June in the years of 1977 to 1982, participation rate varied between 92 and $58 \%$. Fifty percent of the children were followed up through the whole period of our study. All children included in our study were clinically healthy and any pathological conditions were excluded by a routine biochemical blood profile at every visit. None of the children were taking any drugs regularly, except some girls, who took oral contraceptives during the last year of the study. The results from these girls were calculated separately, and no significant differences could be found; therefore results of all girls are presented together.

Blood was drawn in the morning after an overnight fast from a cubital vein of each child, and height, weight, skinfold thickness and blood pressure were measured. Blood samples were allowed to clot at room temperature, followed by centrifugation to obtain serum. Estimation of the different parameters was performed on a Greiner GSA II Analyzer. Alkaline phosphatase was estimated by a modification of the method of $M c$ Comb \& Bowers $(6,7)$ as described by Küffer (8); calcium and inorganic phosphorus were estimated according to the methods of Küffer (9) and Richterich (10), respectively.

\section{Results}

\section{Growth}

Mean heights are shown in figure 1. At ages 11 to 13 years boys and girls were approximately the same size, both of them showing statistically highly significant increments in body height from one year to the next $(\mathrm{p}<0.001)$. After the age of 13 the increase 
in height was less in girls, but still significant until the age of 14 ( $p<0.01$ ); afterwards no significant increment could be shown. In boys, however, height increased significantly from year to year until the age of 16; from the age of 14 onwards boys were significantly taller than girls. Peak growth velocity occurred in girls between the ages of 11 and 12 years with a mean growth of $5.94 \pm 1.92 \mathrm{~cm} /$ year and in boys between the ages of 12 and 13 years $(7.73 \pm$ $2.4 \mathrm{~cm} /$ year; table 1).

\section{Alkaline phosphatase}

Serum alkaline phosphatase activity showed typical sex-related changes with age, boys having constantly higher levels than girls from the age of 13 onwards (fig. 2). The highest mean values in girls were observed at the age of 11 years $(470.9 \pm 114.8 \mathrm{U} / \mathrm{l})$;

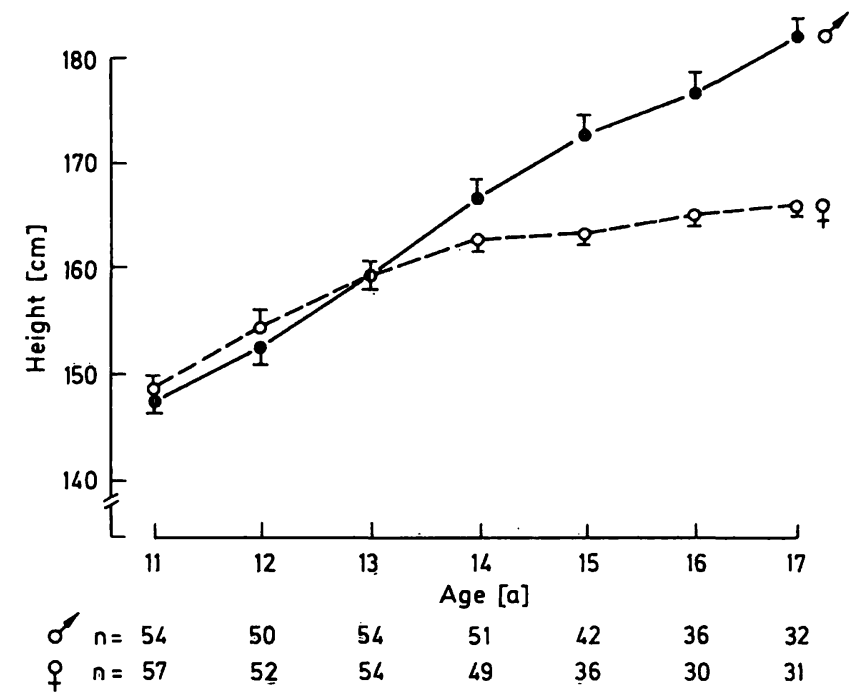

Fig. 1. Growth in healthy Austrian school children 11 to 17 years of age. Height given as $\overline{\mathrm{x}} \pm$ SEM. thereafter, the mean values declined markedly between 13 and 14 years and reached adult levels at the age of 16 . In boys alkaline phosphatase activity increased until the age of 13 and then began to fall, but did not reach adult levels until the age of 17 . There was a statistically significant difference between boys and girls $(\mathrm{p}<0.001)$ between the ages of 13 to 17 years. No significant differences between those girls taking oral contraceptives and the other girls could be shown. Ranges of alkaline phosphatase were very wide, the highest observed values occurring in a 12 year old girl $(939 \mathrm{U} / \mathrm{l})$ and in 13 year old boy $(917 \mathrm{U} / 1)$. Growth during the preceding year was significantly correlated with alkaline phosphatase activity, except for girls in the last year (tab. 2).

\section{Inorganic phosphorus $\left(P_{i}\right)$}

In both boys and girls, $P_{i}$ levels declined constantly with increasing age, boys showing significantly higher mean values than girls between the ages of 13 to 15 years. Between the ages of 16 to 17 years a significant increase could be shown for both sexes (fig. 3). Correlations between alkaline phosphatase and $P_{i}$ were significant in many cases (tab. 3).

\section{Total calcium ( $\mathrm{Ca}$ )}

Mean values increased significantly in boys from the age of 12 to 13 years $(p<0.001)$ and in girls from 13 to 14 years $(p<0.01)$. After the age of 14 , mean values decreased markedly in both sexes (fig. 4). At the ages of 13 and 15 years boys showed significantly higher values than girls. The changes of calcium levels from one year to the next were not accompanied by parallel changes of albumin, although correlation coefficients between these two parameters within one year were statistically significant in most of our calculations (tab. 4).

Tab. 1. Growth velocity in healthy children, 11 to 17 years of age (cm/year) - longitudinal observations, mean $\pm \mathrm{SD}$; min and mạx.

\begin{tabular}{lllllll}
\hline Age (years) & $11-12$ & $12-13$ & $13-14$ & $14-15$ & $15-16$ & $16-17$ \\
\hline Girls & $5.94 \pm 1.92$ & $5.83 \pm 2.49$ & $2.13 \pm 2.05$ & $1.53 \pm 1.45$ & $1.45 \pm 1.05$ & $1.33 \pm 1.11$ \\
& $2-11$ & $0.5-10.5$ & $0-7$ & $0-8$ & $0-4.5$ & $0-4$ \\
& $\mathrm{~N}=52$ & $\mathrm{~N}=48$ & $\mathrm{~N}=38$ & $\mathrm{~N}=33$ & $\mathrm{~N}=30$ & $\mathrm{~N}=26$ \\
Boys & $5.17 \pm 3.98$ & $7.73 \pm 2.40$ & $6.71 \pm 4.54$ & $5.71 \pm 2.87$ & $4.56 \pm 2.79$ & $2.88 \pm 2.16$ \\
& $2-11.5$ & $3.5-13$ & $2-11.5$ & $0.5-10$ & $0.5-11$ & $0-8$ \\
& $\mathrm{~N}=48$ & $\mathrm{~N}=48$ & $\mathrm{~N}=41$ & $\mathrm{~N}=40$ & $\mathrm{~N}=35$ & $\mathrm{~N}=30$ \\
\hline
\end{tabular}




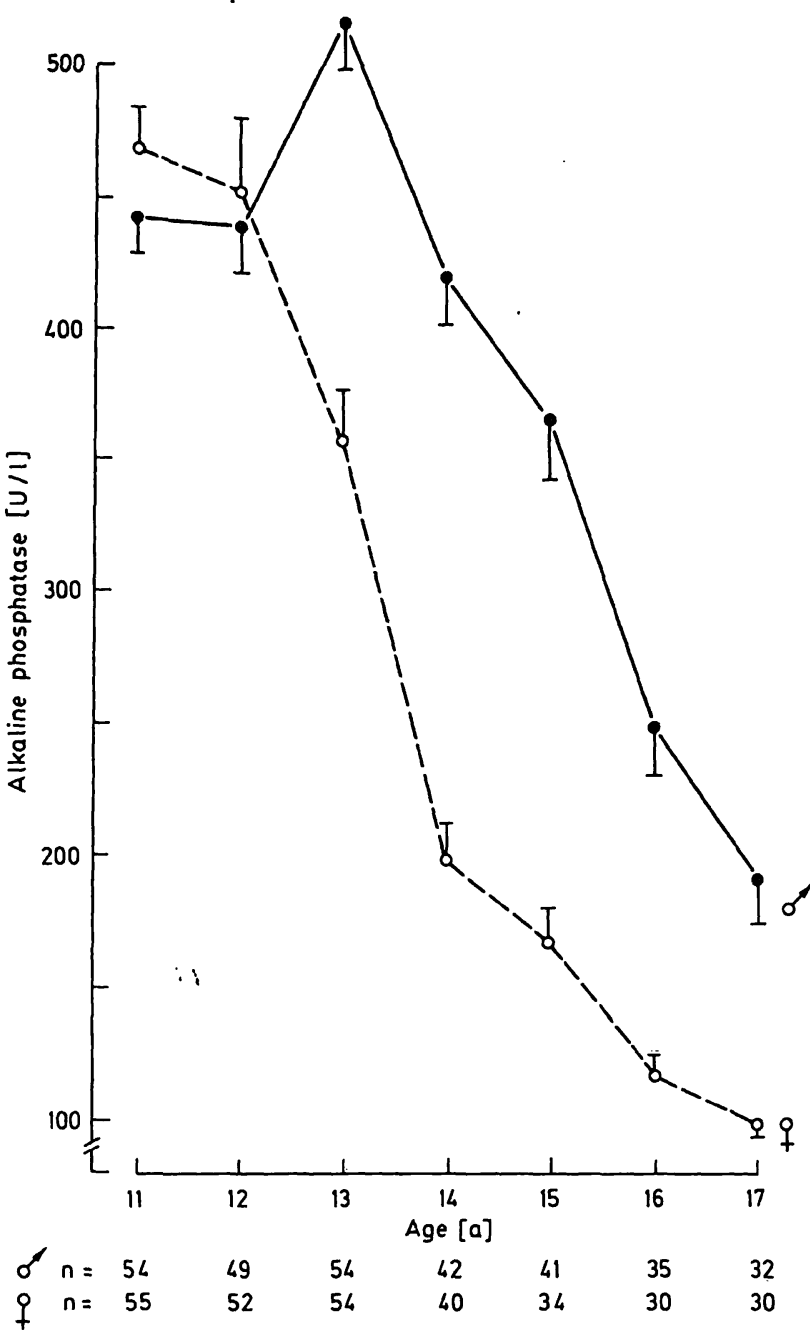

Fig. 2. Age-related changes of alkaline phosphatase activity in sera of healthy Austrian school children, 11 to 17 years of age. Values given as $\bar{x} \pm$ SEM.

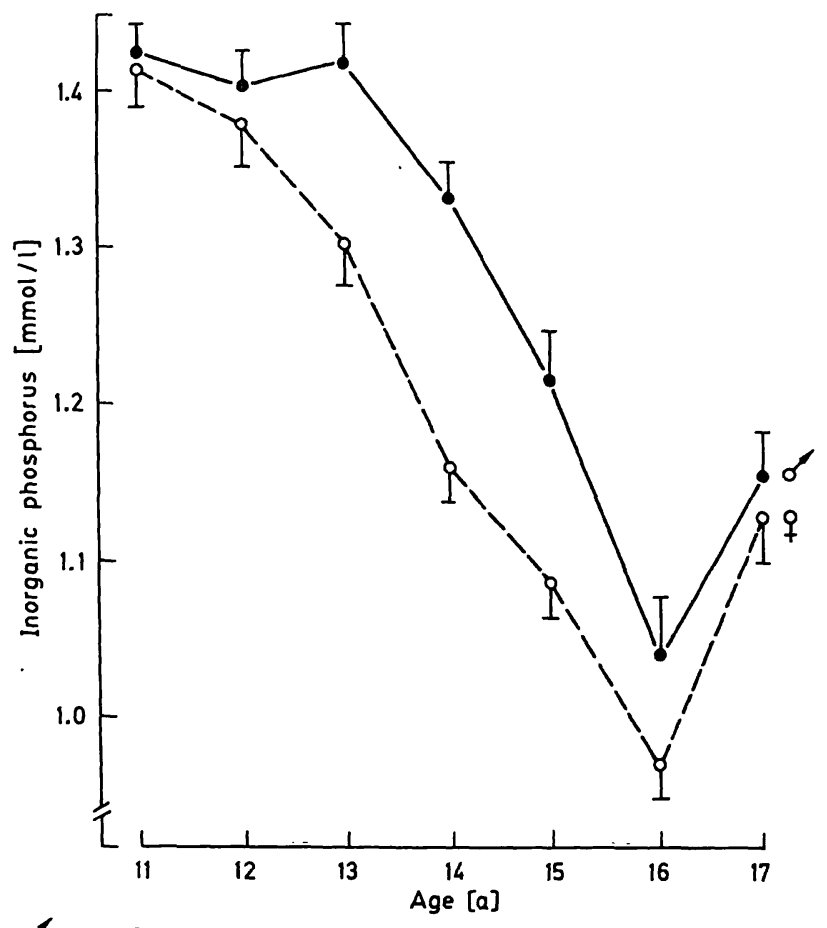

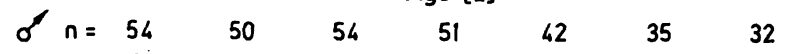

$q n=\begin{array}{lllllll}55 & 52 & 54 & 49 & 37 & 30 & 30\end{array}$

Fig. 3. Age-related changes of inorganic phosphorus lèvels in sera of healthy Austrian school children, 11 to 17 years of. age. Values given as $\overline{\mathrm{x}} \pm$ SEM.

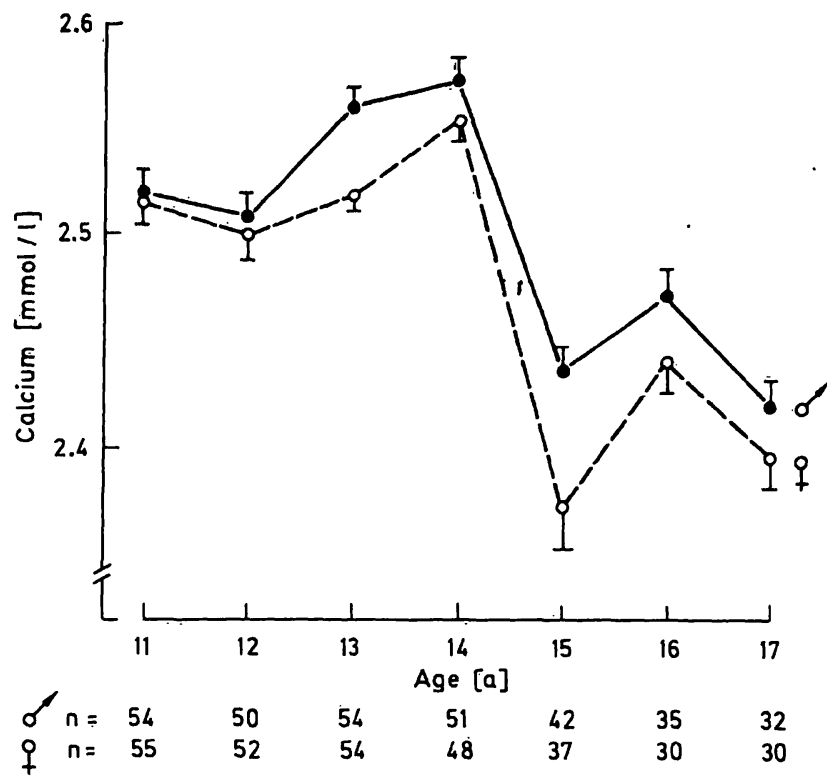

Fig. 4. Age-related changes of total calcium concentration in sera of healthy Austrian school children, 11 to 17 years of age. Values given as $\overline{\mathrm{x}} \pm$ SEM.

\section{Discussion}

To our knowledge no similar longitudinal study over the whole period of adolescence has been published so far.

Our 7 year-"semi-longitudinal"-study showed that there are marked changes of alkaline phosphatase and $\mathrm{P}_{\mathrm{i}}$ levels during adolescence, also for $\mathrm{Ca}$ agerelated changes could be found. Strong correlation between growth velocity and alkaline phosphatase activity levels were observed, as well as significant correlations between alkaline phosphatase and $P_{i}$ and between $\mathrm{Ca}$ and albumin. It must be emphasized that the data from these "semi-longitudinal" evaluations do not differ significantly from those obtained by stricty longitudinal calculations (5).

In comparison with the children investigated by Tanner (27) in 1965 and by Cuncan et al. (28) between 1933 and 1966 our group of children seems to be taller, particularly the older children. This has to be taken into account when former studies are compared with more recent ones, because the attainment of greater height, accompanied by an increased bone growth, might result in higher alkaline phosphatase activity levels.

In general, our findings regarding changes of alkaline phosphatase are in good agreement with those reported by other authors $(1-4,11-16,21-23)$, although the results of these studies cannot be compared directly because of the different methods and 
Tab. 2. Correlation coefficients between growth and alkaline phosphatase activity at different ages.

\begin{tabular}{lllllll}
\hline Age (years) & $11-12$ & $12-13$ & $13-14$ & $14-15$ & $15-16$ & $16-17$ \\
\hline Girls & 0.3055 & 0.5832 & 0.6709 & 0.7062 & 0.4971 & 0.2820 \\
& $\mathrm{p}<0.05$ & $\mathrm{p}<0.001$ & $\mathrm{p}<0.001$ & $\mathrm{p}<0.001$ & $\mathrm{p}<0.01$ & $\mathrm{n} . \mathrm{s}$. \\
& $\mathrm{N}=52$ & $\mathrm{~N}=48$ & $\mathrm{~N}=38$ & $\mathrm{~N}=33$ & $\mathrm{~N}=30$ & $\mathrm{~N}=26$ \\
Boys & 0.3401 & 0.5872 & 0.4370 & 0.8011 & 0.6584 & 0.5993 \\
& $\mathrm{p}<0.05$ & $\mathrm{p}<0.001$ & $\mathrm{p}<0.01$ & $\mathrm{p}<0.001$ & $\mathrm{p}<0.001$ & $\mathrm{p}<0.001$ \\
& $\mathrm{~N}=49$ & $\mathrm{~N}=48$ & $\mathrm{~N}=41$ & $\mathrm{~N}=40$ & $\mathrm{~N}=35$ & $\mathrm{~N}=30$ \\
\hline
\end{tabular}

Tab. 3. Correlation coefficients between inorganic phosphorus and alkaline phosphatase activity at different ages.

\begin{tabular}{llllllll}
\hline Age (years) & 11 & 12 & 13 & 14 & 15 & 16 & 17 \\
\hline Girls & n. s. & 0.3719 & 0.4388 & n. s. & 0.6601 & 0.5913 & n.s. \\
& & $N=49$ & $N=54$ & & $N=41$ & $N=35$ & $p<0.001$ \\
& & $p<0.01$ & $p<0.001$ & & $p<0.001$ & n. s. & n.s. \\
Boys & n. s. & 0.3446 & 0.4233 & 0.5036 & 0.7080 & \\
& & $N=52$ & $N=54$ & $N=40$ & $N=32$ & \\
& & $p<0.05$ & $p<0.01$ & $p<0.001$ & $p<0.001$ & \\
\hline
\end{tabular}

Tab. 4. Correlation coefficients between total calcium and albumin at different ages.

\begin{tabular}{llllllll}
\hline Age (years) & 11 & 12 & 13 & 14 & 15 & 16 & 17 \\
\hline Girls & 0.3879 & n. s. & 0.3335 & 0.3741 & n. s. & 0.6138 & n. s. \\
& $N=55$ & & $N=54$ & $N=49$ & & $\mathrm{~N}=30$ & $\mathrm{p}<0.001$ \\
& $\mathrm{p}<0.01$ & & $\mathrm{p}<0.05$ & $\mathrm{p}<0.01$ & & 0.5747 & 0.4277 \\
Boys & 0.4612 & n. s. & 0.2856 & 0.4596 & 0.4250 & $\mathrm{~N}=35$ & $\mathrm{~N}=32$ \\
& $\mathrm{~N}=54$ & & $\mathrm{~N}=54$ & $\mathrm{~N}=51$ & $\mathrm{~N}=39$ & $\mathrm{~N}=35$ \\
& $\mathrm{p}<0.001$ & & $\mathrm{p}<0.05$ & $\mathrm{p}<0.001$ & $\mathrm{p}<0.01$ & $\mathrm{p}<0.001$ & $\mathrm{p}<0.05$ \\
\hline
\end{tabular}

different units used. The "normal ranges" reported vary within wide limits, and due to the different methodology they cannot be used for our study. Therefore only relative trends can be compared.

As early as 1939, Vermehren (1) reported on an increase of alkạline phosphatase activity at the onset of puberty; in his study girls reached their mean peak levels between the age of 11 and 13 years and showed a decrease from the age of 13 years onwards, whereas in boys serum alkaline phosphatase activity only started to increase at the age of 13 after an initial decline at 11 and 12 years; peak levels were reached at the age of 17 . Later studies $(11-14)$ reported an initial increase of alkaline phosphatase activity at the onset of puberty, with girls reaching their peak levels 2 to 3 years earlier than boys, and showing a more rapid decline towards adult levels. Boys showed constantly higher values than girlș. Similar observations were made by Clark \& Beck (2), although they did not find the initial increment in girls - a phe- nomenon which is confirmed by our results. In their longitudinal investigation Clark \& Beck were able to show a close correlation between growth and serum alkaline phosphatase activity. This finding is confirmed by Round et al. (23) who used sexual maturity ratings (SMR) instead of annual age and were able to show that the peak growth velocity and the peak serum alkaline phosphatase activity in girls did not only occur at an earlier age, but also at an earlier maturity stage (16). Similar results are reported by Bennett et al. (15). In most of the previous published studies a close correlation of alkaline phosphatase activity to growth spurt during adolescence was observed $(2,3,15,23)$. In addition, it has been shown that the high alkaline phosphatase during this phase of growth is mainly derived from osteoid tissue, thus reflecting the high activity of bone tissue (2). But whether these changes during adolescence are mainly due to the changing activity of growth hormone or mainly due to sex hormones has not yet been investigated. 
Kantero et al. published in 1975 a study on 146 healthy girls before and after the menarche. They reported that the growth spurt was accompanied by a rise of both steroid secretion and serum growth hormone. Furthermore, they observed that the increased growth hormone concentrations seem to be accompanied by elevated levels of alkaline phosphatase (17). Nevertheless, the role of growth hormone in the growth spurt during adolescence does not seem to be quite clear: In this regard Heald \& Hung, on the other hand, state that growth hormone is not required for the adolescent growth spurt (18).

Inorganic phosphorus serum levels are generally reported to decrease from childhood to adulthood (1, $12,19,20,24,25)$ and the "normal ranges" are about the same in most of the reports. Round (21) reported a constant fall from childhood levels at the age of 7 years to normal adult levels, which were reached in girls at the age of 15 and in boys at the age of 17. Between the ages of 8 to 16 years girls showed significantly lower values than boys. These results are in good agreement with our findings; in our study, however, boys showed significantly higher levels than girls only at ages 13 to 15 years and levels increased significantly between 16 and 17 years. De Wijn (22), on the other hand, found an increase of inorganic phosphorus at the beginning and a decrease in the last part of adolescence in boys; these changes suggest a correlation with development of muscle mass caused by an increased growth hormone activity or by androgens (22). These findings were later supported by Round by means of a longitudinal study, when she also found a significant rise of inorganic phosphorus levels in boys at the onset of puberty (23). In 1955 Hamilton et al. studied the relationship between inorganic phosphorus levels and urinary ketosteroids and androgens in men over an extensive age range (24). However, they did not find significant correlation between these parameters, although earlier observations indicate that androgens might

\section{References}

1. Vermehren, E. (1939) Acta Med. Scand. 100, 244-253.

2. Clark, L. C. \& Beck, E. (1950) J. Pediatr. 36, 335-341.

3. Salz, J. L., Daum, F. \& Dohen, M. I. (1973) J. Pediatr. 82, $536-537$.

4. Werner, M., Tolls, R. E., Hultin, J. V. \& Mellecker, J. (1970) Z. Klin. Chem. Klin. Biochem. 8, 105-115.

5. Widhalm, K., Hölzl, M. \& Brubacher, G. (1985) Ann. Nutr. Metab. 29, 12-18.

6. Bowers, G. N. \& McComb, R. B. (1966) Clin. Chem. 12, $70-89$.

7. McComb, R. B. \& Bowers, G. N. (1972) Clin. Chem. 18, 97-104. influence the blood concentration of $\mathrm{P}_{\mathrm{i}}$; in another study Hamilton et al. reported that $\mathrm{P}_{\mathrm{i}}$ levels are elevated in subjects with gonadal dysgenesis, in eunuchoidism, in hypopituitarism and after castration (26). The close relationship between $P_{i}$ and alkaline phosphatase shown in our study has also been observed by Werner et al., who found that the age and sex-dependent changes of $P_{i}$ shown in their study are concomitant with those found for alkaline phosphatase, correlation coefficients were not reported (4).

The published data for the changes of calcium levels during adolescence are contradictory. Cheng (12) studied 837 healthy children and reported a steady decline of total calcium throughout childhood; boys showing significantly lower values than girls between the age of 12 to 14 years. On the other hand, Werner et al. found an increase of serum calcium after sexual maturation in males and a decrease in females, and suggested that these changes are secondary to changes of albumin and total protein, because of the highly significant correlations between serum calcium and age (4). These findings are in agreement with the findings of Cherian \& Hill, who described a statistically significant relationship with age; they reported slightly decreased calcium concentrations in females and slightly increased levels with age in males (20). To our knowledge, an increase in both sexes, between the age of 12 and 13 years, as observed in our study, has not been reported before.

Concluding our results, it should be pointed out, that the marked changes of alkaline phosphatase and inorganic phosphorus observed during the adolescent growth spurt were confirmed by a longitudinal follow up study. These changes are probably due to growth and variations of sex hormone levels. Furthermore, an increase of total calcium values, which also seem to be influenced by growth and puberty, was established for both sexes.
8. Küffer, H. \& Richterich, R. (1973) Quad. Sclavo Diagn. 9, 61.

9. Küffer, H. \& Degiampietro, P. (1975) Clin. Chem. 21, 961.

10. Richterich, R. (1971) Klinische Chemie, Theorie und Praxis, Basel, Karger, p. $234=235$.

11. Fleisher, G. A., Eickelberg, E. S. \& Elveback, L. R. (1977) Clin. Chem. 23, 469-472.

12. Cheng, M. H., Lipsey, A. I., Blanco, V., Wong, R. H. \& Spiro, S. H. (1979) Clin. Chem. 25, 692-298.

13. Cherian, A. G. \& Hill, J. G. (1978) Am. J. Clin. Pathol. $70,783-789$. 
14. Penttilä, I. M., Jokela, H. A. \& Viitala, A. J. (1975) Scand. J. Clin. Invest. 35, 275-284.

15. Bennet, D. L., Ward, M. S. \& Daniel, W. A. (1976) J. Pediat. 88, 633-636.

16. Round, J. M. (1980) Ann. Hum. Biol. 7, 83-88.

17. Kantero, R. L., Wide, L. \& Widholm, O. (1975) Acta Obstet. Gynaecol. Scand. 54, 1-8.

18. Heald, F. P. \& Gung, W. Adolescents endocrinology 1970. Haddon Craftsmen, Inc., Scranton, PA, New York.

19. Greenberg, B. G., Winters, R. W. \& Graham, J. B. (1960) J. Clin. Endocrinol. Metab. 20, 364-378.

20. Cherian, A. G. \& Hill, J. G. (1978) Am. J. Clin. Pathol. $69,24-31$.
21. Round, J. M. (1973) Brit. Med. J. 3, 137-140.

22. De Wijn, J. F. (1965) Helv. Paediatr. Acta 20, 497-526.

23. Round, J. M., Butcher, S. \& Steele, R. (1979) Ann. Hum. Biol. 6, 129.

24. Hamilton, J. B., Bunch, L. \& Hirschman, A. (1956) J. Clin. Endocrinol. Metab. 16, 463-472.

25. Bullock, J. K. (1930) Am. J. Dis. Child. 40, 725-740.

26. Hamilton, J. B., Bunch, L. D., Mestler, G. E. \& Imagawa, R. (1956) J. Clin. Endocrinol. Metab. 16, 301-321.

27. Tanner, J. M., Whitehouse, R. H. \& Takaishi, M. (1966) Arch. Dis. Childh. 41, 613-635.

28. Duncan, B., Lubchenco, L. O. \& Hansman, Ch. (1974) Pediatrics $54,497-502$.

Doz. Dr. K. Widhalm

University of Vienna

Dept. of Pediatrics

Währinger Gürtel $18-20$

A-1090 Wien 
